\title{
Enigmatic Calligraphy: Lettering as Visualized Hermeneutic of Sacred Scripture
}

\begin{abstract}
The introductory pages, which in early medieval gospel books are placed at the beginning of a gospel, often stage an antithesis of enigmatic calligraphy and clear legibility. As a visual reflection on writing and script this juxtaposition is related to a hermeneutic of Holy Scripture. The initial pages in particular demonstratively break the rules of readable and linearly ordered script. They do not require reading in the usual sense, which linearly follows the succession of words. As 'script-images' they must be contemplated by simultaneous consideration, that should reveal a meaning behind the material letters. Their illegibility can be understood as a visual cue for the transition from meditative reading to contemplatively seeing the purely intelligible.
\end{abstract}

\section{Incipit openings as 'critical form'}

In a gospel book from the Leipzig Universitätsbibliothek (Ms. 76), written in the first half of the tenth century in the monastery of Corvey in Westphalia, each of the four gospels is introduced by two double pages. ${ }^{1}$ Their sequence is the same for each gospel. The first opening starts with the incipit on the verso page, five or six lines with large capitals written in gold. The recto page opposite displays an initial and the first letters or words of the Gospel, also written in gold and richly decorated (Figs 2 and 3). The following opening is written in uncial script. On the left page the continuation of the gospel text appears in silver on a field of purple. The parchment on the right is uncoloured, and the lines of text are double spaced. On the verso of this folio, the text continues in Carolingian minuscule. The whole series is structured according to a hierarchy of script that starts with large capitals and ends with minuscule. The artistic effort follows this hierarchy and marks the first opening as the highpoint of the sequence. Both pages of this opening are surrounded by a wide and ornamented frame, and the page with the beginning of the gospel shows an artistic arrangement of letters and ornamentation.

$1<$ http://www.manuscripta-mediaevalia.de/dokumente/html/obj31560411> (accessed on 28 Oct. 2020). Bauer 1977, 2: 89-100; Kahsnitz 2001. 
Initial pages featuring a composition of letters, words, ornamentation, and sometimes images, all artfully combined and interwoven with each other as in the Leipzig gospel book, are widespread in early medieval European manuscript culture. Regarded as highlights of the art of writing and book illumination in the Medieval Latin West, these initial pages exhibit the artistic imagination and creativity of scribes and painters. ${ }^{2}$ Since the late eighteenth century, this estimation of decorated pages has also led to them being separated from their respective manuscripts and traded and collected as single sheets, like autonomous works of art. ${ }^{3}$ For a long time, this perception has obscured the important role these pages play in the overall structure of their original manuscripts. Usually placed at the beginning of a work, a chapter, or an important passage, such pages help to structure the codex. In early medieval gospel books, these initial pages are regularly found at the beginning of each of the four gospels, and such pages are at the same time part of a sequence introducing those gospels. In addition to the initial page, this sequence can include incipit pages, the respective evangelist's image, and pages exhibiting only ornamentation, a coloured field, or, as in the case of the Leipzig gospels, a specially written text. In a sometimes slightly varied order, all these pages form a fixed set of decorated pages, such as developed early on in insular manuscript culture. ${ }^{4}$ This set that clearly marks, on the one hand, the four parts of the gospel book and, on the other hand, its unified appearance expresses the unity and harmony of the fourfold gospel.

There is no fixed terminology for labelling pages with display script, that is, with decorated and enlarged characters. According to their content, one can speak of incipit and initial pages. Terms such as 'ornamental', 'decorated', or 'decorative pages' primarily refer to their aesthetic and artistic value. It is obvious that these terms focus on functions such as decoration and embellishment, and of course, embellishment and decor are among the aims of these pages. They invite aesthetic appreciation and contribute to the manuscript's aura, which may be due to many factors. ${ }^{5}$ Gospel books, for example, represent Christ himself and contain his Holy Word. ${ }^{6}$ Accordingly the artistic and material effort expended on these pages, evident in rich ornamentation, in colours, and in gold

2 The basics and a general overview about the form and function of initials are given by Gutbrod 1965; Nordenfalk 1970, esp. 117-134; Alexander 1978; Pächt 1985, 45-95; Jakobi-Mirwald 2004, 178-187.

3 Wieck 1996.

4 Brown 2017.

5 Rohrbach 2008, 200-202.

6 Kendrick 1999, 65-109; Heinzer 2009; Palazzo 2010; Reudenbach 2014. 
and silver, make visible the preciousness and sacredness of the word of God, even though, especially in early Christianity, precious writing material could also be regarded with scepticism and reserve. ${ }^{7}$ Above all, however, it has often been shown that ornamented pages with decorated letters cannot be regarded as only decorative; they also visually convey a lot of other information, in addition to the wording of the script.

From half a century ago in the field of insular art, we have path-breaking studies by Werckmeister or Lewis, which deal with insular examples such as the famous Chi-Rho-page of the Book of Kells. ${ }^{8}$ Such scholars discussed the concrete meaning of ornamental motifs beyond the aspect of embellishment, and they explained the often highly sophisticated iconography of initial letters. Recently, scholars of medieval art have further developed this approach, referring in their discussion of such pages to a methodological concept called 'graphicacy', which focuses on the meaning of non-figural graphic forms. ${ }^{9}$ It seems that insular art and a proximity to an iconographic methodology remain the dominant interests of most of these studies. ${ }^{10}$ Their great merit is that they reveal these pictorial elements as a complex, coherent, and meaningful visual system composed of decorated letters, ornamentation, geometric forms, and images, rather than understanding such elements as merely decorative or as an external adjunct to the script. It is obvious that in addition to the general visual organization of the pages, and in addition to the design or ornamental framing of the text, decorated initials are particularly suitable objects of study for scholars interested in the extra-linguistic properties of writing. ${ }^{11}$ This aspect of lettering is also central to the concept of Schriftbildlichkeit, which in this respect bears some similarity to the term 'graphicacy'. For Schriftbildlichkeit also deals with the iconic dimension of writing, with the connection of script to imagery rather than to language. ${ }^{12}$

7 Seen. 28.

8 Werckmeister 1964, 1967, esp. 147-170; Lewis 1980.

9 Garipzanov 2015; see also the introduction in Brown et al. 2017. Related is the approach to unfigürlicher Ikonographie ('non-figural iconography') by Victor H. Elbern; see his summary article, Elbern 1983.

10 Tilghman 2011a, b, 2016, 2017; Garipzanov 2017; Karkov 2017.

11 Tilghman 2011a; Garipzanov 2017; Karkov 2017. See also the article by Erika Loic, which deals with the materiality of script and focuses on self-reflexive initials that contain images of authorship and scribal practice, which the author describes as a 'networking structure' (Loic 2020).

12 Krämer et al. 2012. See also Hamburger 2011; Christin 2016; Polaschegg 2018, 177. For the relationship between display scripts and ornament, see Bonne 1996 and Ganz 2017a, 126-127. 
These scholarly impulses are taken up in this article, but the focus is neither on insular art nor on the iconography of letter shapes, ornamentation, or nonfigural motifs. This article's focus is rather on a certain combination of pages, as can be found several times in liturgical books written in the Carolingian and Ottonian empires from the ninth to the eleventh century. The gospel books of this era almost always contain the aforementioned series of pages introducing each gospel. Within this sequence, the actual beginning of the text, the socalled initial page, is often so dominated by the ornamental mode that deciphering letters and reading words is very difficult or even impossible. This illegibility cannot $a$ priori be explained as a sign of appreciation and esteem for writing and Sacred Scripture, especially when we are talking about manuscripts that are, at least in part, intended for liturgical reading. Of course, no cleric needed to actually read the beginning of a gospel because everyone knew it by heart. In fact it can be said that display script was often used for formulas or beginnings that most readers knew by heart. ${ }^{13}$ Nevertheless, that illegibility is associated with great artistic effort in manuscripts intended for reading, is not self-evident and requires an explanation. Moreover, the initial page that is difficult or impossible to read is juxtaposed with clear legibility and a completely different mode of writing on the following or preceding page; an example is the incipit of the previously mentioned Leipzig gospels, which is written in capital letters (Fig. 2).

This remarkable arrangement is difficult to notice if one considers decorated initials to be an isolated phenomenon, and if one understands them solely as an artistic form and an aesthetic sensation to be explained by the methods of analysing form, style, or iconography. ${ }^{14}$ No page of an elaborately designed manuscript, however, is an isolated work, despite the practice of cutting out and collecting single leaves. Rather, that leaf forms a continuum with the preceding and following pages and occupies a very specific place in the architecture of the manuscript. ${ }^{15}$ Particularly the introductory sequence of the gospels is consciously and calculatedly designed such that every element is related to each other. In this respect, the presentation of two fundamentally different modes of writing and the direct juxtaposition of legibility and illegibility is remarkable and meaningful. Such an opening appears as a 'critical form' that

13 Ganz 2017a, 131.

14 An exception is O’Driscoll 2011.

15 For the importance of double pages as units, see Toubert 1990; Schneider 2000, 2002; Hamburger 2010; Ganz 2016. 
pertains to the specific status of script in a gospel book. It visually expresses an attitude towards the written word of God. ${ }^{16}$

\section{Initial pages between legibility and illegibility}

To pursue and justify this thesis, we shall first take a closer look at the set of pages introducing each gospel in the gospel book from Leipzig. As already explained, the incipit and the beginning of the respective gospel text are placed next to each other on the first double page, e. g. in Luke's Gospel (Figs 2 and 3) 'INCIPIT EVANGELIVM SECVNDVM LVCAM' on the left (fol. 109') and 'QVONIAM QVIDEM' on the right (fol. $110^{\mathrm{r}}$ ). Both pages are clearly marked as belonging together, as their size, colour, and an ornamented frame indicate. But at the same time, they are quite different. The wording of the incipit is written in large capitals and exactly in five lines, clearly legible, while the 'QVONIAM QVIDEM' can hardly be deciphered at all. The usual arrangement of letters, which constitutes words and makes them readable, and the sequence of characters in horizontal lines from left to right are completely negated and destroyed, with the result that we see more of an ornamental mesh than two written words. The large and ornamented initial letter $Q$ is placed in the centre. The following letters, of different sizes, are freely grouped around it but interwoven with each other and with golden interlace in such a way that they are very difficult to identify completely. The visual organization of the page is closer to that of a monogram or a centralized image than to continuous script. ${ }^{17}$ These observations equally apply to the other three gospel beginnings in the Leipzig gospel book.

Examination of another gospel book, which was also written in the tenth century at the Corvey monastery and is now in the Pierpont Morgan Library (M. 755), reveals similar features. ${ }^{18}$ In this case, however, the introductory sequence of all four gospels is arranged in an unusual way; incipit and initial page do not appear as a double page, but on recto and verso of the same folio. ${ }^{19} \mathrm{Be}-$ cause of this arrangement, the beginning of the gospel text is in the centre of the sequence, starting with the initial page and continuing on the opposite recto.

16 Here I follow the important and stimulating considerations Tobias Frese has offered on a special constellation, namely, the double page at the beginning of the Gospel of Mark in the Hildesheim Guntbald Gospel (1011): Frese 2014, 4-8.

17 Otto Pächt uses the term Monogrammseite ('monogram page'): Pächt 1985, 63-76.

18 Bauer 1977, 2: 41-49; Euw 1991, 59-61, no. 10 (Gerd Bauer); O’Driscoll 2011.

19 Bauer 1977, 1: 128-132, 156-183; O’Driscoll 2011, 314. 
All pages of the introductory sequence are emphasized by frames and by patterned and coloured writing surfaces. The initial page with the first words of the gospel text is especially prominent due to the size of the decorated initial, which takes up the entire height of the full-page framed area, and exhibits a systematic disturbance or even destruction of readability.

The initial page of Matthew (fol. $17^{\mathrm{v}}$ ) 'LIBER GENERATIONIS IHV XRI FILII DAVID FILII ABRAHAM' ('The book of the genealogy of Jesus Christ, the Son of David, the son of Abraham') (Fig. 1), for example, displays the large initial L on the left, in the upper part of which the following I is set. To the right of this are four groups of large golden letters - (LI) BER / GENE / RATIO / NIS - which are intertwined with each other and with tendrils to form a dense network that can hardly be disentangled by the eye. The following words IHV XRI FILII DAVID, on the other hand, are written in much smaller golden capitals. But they are not directly connected to LIBER GENERATIONIS at the bottom. Rather, they appear in a single line at the top and continue in descending order with FILII ABRAHAM immediately next to the initial $\mathrm{L}$.

The visual organization of the page thus follows the hierarchy of fonts, from the large initial in descending order to the small capitals. At the same time, however, the usual arrangement of words, one after the other from left to right and in lines from top to bottom, has been destroyed. The reader's eye is forced to change directions and make abrupt jumps on the page. In addition, the clear and concise capitals are juxtaposed with letters that are difficult or even impossible to identify due to the interwoven ornamentation.

The beginning of the Gospel of John (fol. 157") 'IN PRINCIPIO ERAT VER$B U M$ ' (In the beginning was the Word) is similarly designed and composed; it contains the same formal elements: initials, large gold letters intertwined with ornamentation, and small capitals (Fig.4). Here the large initial I forms the central axis of the page, spanning its entire height; on the right are three groups of large decorated letters, N / PR / IN, arranged like a column and corresponding to the letters CI / PI / O on the left of the large initial I. This arrangement is augmented by the small capitals ERAT VERBV(m) that are written at the top of the page, beneath the upper frame.

Here, too, reading directions are from right to left or in vertical instead of horizontal sequence. The organization of the entire page is oriented more towards the mode of an image than that of writing. The shaft of the large initial I, with the letters PI and PR on the left and the right, forms an ornamented cross, dividing the framed field into four quadrants. In this way the beginning of the Gospel, which formulates the equation of the body of Christ with the Holy Word, is connected with the cross. The written 'image' puts the incarnation and 
Christ's death on the cross in a relationship and thus also confirms that letters do not merely record the words of the gospel. The broad field of theological discourse and symbolic interpretation that the appearance of the page opens up cannot be pursued here. Of particular interest for present purposes, however, is the function of illegibility and the visual and artistic procedures that make reading difficult or impossible. These procedures include hiding letters in an ornamental mesh, abruptly changing the font and letter size, disrupting words, and negating the usual reading direction by arranging letters either from right to left or in a vertical instead of horizontal order.

Obviously, these principles of visual organization go beyond the qualities that scholars have always attributed to decorated letters alone. As a combination of letter form and ornament, decorated initials have an 'illogical connection' with a resulting 'loss of legibility'. ${ }^{20}$ This may be true for the individual decorated letter; but on the pages that have been described here, pages which contain complete word sequences apart from the initial, the reduced legibility is only partially due to the ornamentalisation of the letters. Rather, a systematic break with the rules of normal writing is evident here, through the unexpected alteration of font, letter size, and reading direction or through the abandonment of ruled writing in favour of a free and seemingly arbitrary positioning of the letters on the writing area.

We are not dealing with pages that show a generally illegible script, but rather with pages that oscillate between legibility and illegibility. Individual, clearly identifiable, and legible letters challenge the reader to read, while the writing in the immediate vicinity may be closed off to legibility by a texture of ornamentation. ${ }^{21}$ This simultaneity of openness and enigma can be present on a single page, as in the Liber generationis page of the Morgan gospels (Fig. 1). But it can also determine the composition of an opening, in which an ornamentally closed page is juxtaposed with a page that displays the text in large letters, as in an inscription on a stone tablet (Figs 2 and 3).22

In addition, on the remaining pages of the introductory sequence, we observe another method that can obscure the script and disguise the text, a method that was very popular in the tenth and eleventh centuries. In these cases the

20 Alexander 1978, 8-9.

21 Polaschegg 2018, 176-182, with general remarks on the history of the perception and use of illegible scripts, i.e. 'really existing writings that can be recognised but not read' (176).

22 This arrangement can be found, e.g. in the Leipzig gospels at the beginning of each gospel (fols $12^{\mathrm{v}} / 13^{\mathrm{r}} ; 71^{\mathrm{v}} / 72^{\mathrm{r}} ; 109^{\mathrm{v}} / 110^{\mathrm{r}} ; 177^{\mathrm{v}} / 178^{\mathrm{r}}$ ) or in Morgan gospels at the beginning of Mark (fols $64^{\mathrm{v}} / 65^{\mathrm{r}}$ ) and Luke (fols $99^{\mathrm{v}} / 100^{\mathrm{r}}$ ). 
text is written on a patterned writing surface. The background can be so dominant that it is difficult to see the golden lines of the text. The patterned writing area often alludes to the patterns of textiles, mostly of precious silk from the East. ${ }^{23}$ From here it is only a small step to pages that are part of the introductory series, but on which only coloured areas or fields with textile patterns appear, without any writing at all. In the famous Codex aureus Epternacensis (c. 1030) from Nuremberg, Germanisches Nationalmuseum (Hs. 156142), each of the extensive sequence of pages introducing the four gospels even includes a double page, up to the outermost edge of the parchment, that is exclusively and completely covered with a pattern reminiscent of textiles. ${ }^{24}$

In a Gospel book from the treasury of St. Gereon, which was written around 990/1000 in Cologne, the page preceding the images of the evangelist contains only a framed blueish-purple or reddish-purple field..$^{25}$ The same is the case with a gospel book that was also made in Cologne, perhaps originating from St. Andreas, and which is dated to the first half of the eleventh century. ${ }^{26}$ These pages are usually referred to only as 'coloured' or 'decorated', as 'textile' or even very misleadingly as 'carpet' pages. Because they appear without writing, they have often been considered unfinished, even though the respective manuscript does not otherwise provide any evidence of this unfinished state. In this respect, the famous Gospel of St. Maria ad Gradus in Cologne (c. 1030) is revealing. ${ }^{27}$ The first page introduces not the first gospel but the manuscript as a whole and contains a purple field without any writing on fol. $1^{\mathrm{r}}$, followed by an illumination of the Maiestas Domini on fol. $1^{\text {v }}$. In a sequence of this sort, no text should be expected on the purple field at all.

If pages that are not covered with writing and contain only colour or ornamentation are also part of the introductory sequence, along with the initial pages, the pages with patterned background, or pages with capitals of demonstrative clarity, then it is necessary to include the wordless pages in the spectrum of the different forms of writing presented there. It is as if letters and words are not hidden in an enigmatic visual organization, but are instead completely invisible. To exaggerate, one could say that these are not pages without writing, but pages with invisible writing. The introductory series thus covers a wide range,

23 Bücheler 2014, 2016.

24 Fols $17^{\mathrm{v}} / 18^{\mathrm{r}}$ (Matthew), fols $51^{\mathrm{v}} / 52^{\mathrm{r}}$ (Mark), fols $75^{\mathrm{v}} / 76^{\mathrm{r}}$ (Luke) and fols $109^{\mathrm{v}} / 110^{\mathrm{r}}$ (John) $<$ http://dlib.gnm.de/item/Hs156142/1> (accessed on 28 Oct. 2020).

25 Cologne, Historisches Archiv, Cod. W 312. Euw 1991, 30-34, no. 2.

26 Darmstadt, Hessisches Landesmuseum, AE 679. Märker and Jülich 2001, 27-37.

27 Cologne, Erzbischöfliche Diözesan- und Dombibliothek, Cod. 1001a. 
from hard-to-read, to illegible, to invisible script - often in juxtaposition with the almost demonstrative clarity of large capitals. This arrangement, which unfolds programmatically at the beginning of each gospel, is to be understood as a visualized reflection on the nature and status of writing and script, which in this case is Holy Scripture, as well as on the recognition of God in the divine Word.

\section{Enigmatic calligraphy and the 'veil of the letter'}

If one looks at the elaborate ornamentation and decorated letters which can be seen on the aforementioned initial pages, it is obvious that such elements do not fit into the ideas and definitions that medieval Christian scholars had of script and letters. Even the Church Fathers rejected more or less the visual luxury of manuscripts containing the word of God. ${ }^{28}$ This attitude was based on a purely functional understanding of writing as a representation of spoken words. For speech, however, the material preciousness of writing is irrelevant. When the Church Fathers condemned and rejected preciously elaborate script, their arguments followed, in some respects, older theories of language and writing, which can be traced back to Aristotle and the Stoics. This attitude was no longer shared by the writers and painters of the Early and High Middle Ages, as the large number of ornamental pages and decorated letters proves. This is true even though Aristotle's teachings remained authoritative for most late antique and medieval scholars and for the early medieval ars grammatica. ${ }^{29}$

Medieval treatises on the ars grammatica, almost all of which go back to ancient Greek and Roman authors, often deal with letters and writing. The definition of letters that exercised the most influence during the Middle Ages comes from the late classical grammarians Diomedes (fourth century) and Priscian (sixth century). The definition states that a letter is determined by three properties, nomen, figura, and postestas, ${ }^{30}$ that is, name ('what is said'), figure ('what is observed or noted with writing'), and phonic value (potestas). ${ }^{31}$ This definition, which is also reported by Isidore of Seville (c. 560-636) in his Etymologiae, ${ }^{32}$ is the consensus definition among early medieval scholars - and it is irrelevant for

28 Nordenfalk 1970, 89-96; Kendrick 1999, 36-39; Tilghman 2011a, 294.

29 Irvine 1994, 30-33.

30 Vogt-Spira 1991, 304-311; Irvine 1994, 97-104; Assmann 1992, 1420.

31 Irvine 1994, 98-100.

32 Isidore of Seville, Etymologiarum sive originum libri XX, I, 4.16. 
the decorated letters discussed here, for which sometimes neither nomen nor figura can be identified. But in a short paragraph about five Greek letters, Isidore also reports on what he calls litterae mysticae ('mystical letters').33 'Mystical' here means that a letter has a disguised meaning beyond its sound, a meaning that is only visually recognizable; Isidore offers symbolic explanations, some of which are deduced directly from the shape of the letters. ${ }^{34}$ These explanations exhibit an awareness of the materiality of writing or even of display lettering, a materiality that can be accessed through iconography; Isidore's specific explanations of Greek letters are less important here than the fact that the 'mystical letters' are not Greek letters by chance. Like all medieval scholars and commentators, Isidore understood Hebrew, Greek, and Latin to be the three sacred languages, with Greek and Latin descending from Hebrew, the original source. ${ }^{35} \mathrm{He}$ and many other grammatical sources constructed a genealogy of script from biblical origins, thus touching on a broad tradition of creation myths in which the invention of script or the origin of texts was linked to supernatural events. ${ }^{36}$

Within the biblical narratives, this tradition is exemplified by the events on Mount Sinai (Ex. 31,18), when God dedit quoque Mosi [...] in monte Sinai duas tabulas testimonii lapideas scriptas digito Dei ('gave to Moses [...] the two tablets of the testimony, tablets of stone, written with the finger of God') and by the scriptura Dei ('the writing of God') (Ex. 32,16). ${ }^{37}$ Narratives such as this one can give people who are concerned with letters and writing a sacred aura. ${ }^{38}$ In this sense writing is understood as bound up with supernatural mysteries and not accessible to everyone. Isidore reports this constellation of ideas and mentions that among the Egyptians the priests and the people had different scripts. ${ }^{39}$

So it can be supposed that this idea of writing - the idea of a script that only a few can understand, a script that appears enigmatic and seems to contain a secret - is still alive in the enigmatic visual organization of the decorated pages.

33 Isidore of Seville, Etymologiarum sive originum libri XX, I, 4.8-9. Ernst 2006, 210. For the iconographic potential of Greek letters in insular manuscripts, see Tilghman 2011b, 101.

34 For other sources, besides Isidore, about the symbolic meaning of letters, see Ganz 2017a, 130; cf. Schreiner 2002, 278-292; Kiening 2008, 31-32.

35 Isidore of Seville, Etymologiarum sive originum libri XX, I, 3.4. Tilghman 2011b, 96.

36 Irvine 1994, 102.

37 Kiening 2008, 22-26. Even the emergence of different languages due to human hubris at the Tower of Babel was 'healed' by divine power, through the descent of the Holy Spirit at Pentecost. For this idea and the use of mixed scripts in gospel books, see Tilghman, 2011b, 101-104.

38 Kiening, 2008.

39 Isidore of Seville, Etymologiarum sive originum libri XX, I, 3.5. 
This enigmatic dimension of writing touches on the fundamental question about the relationship between seeing the written text of Sacred Scripture and a true understanding of these texts as divine revelation and as a means of access to God; this relationship is a special one in Christianity. A famous passage from the Apostle Paul's second letter to the Corinthians sums up this relationship concisely. Paul, referring to the report in Exodus of the stone tablets, writes:

Manifestati quoniam epistula estis Christi ministrata a nobis et scripta non atramento sed Spiritu Dei vivi non in tabulis lapideis sed in tabulis cordis carnalibus.

And you show that you are a letter from Christ delivered by us, written not with ink but with the Spirit of the living God, not on tablets of stone but on fleshy tables of the heart.

(2 Cor. 3,3).

And he continued with the much-quoted striking formula: Littera enim occidit Spiritus autem vivicat ('For the letter kills, but the Spirit gives life') (2 Cor. 3,6). ${ }^{40}$

In contrasting littera et spiritus, letter and Spirit, the apostle refers to the difference between old and new, that is, the Old Testament, which could only be based on the letter of the law, and the New Testament, in which the life-giving Spirit of God could be experienced through Christ himself. Besides this salvationhistorical meaning, in early Christianity Origen in particular understood the Pauline word in the sense of a scriptural hermeneutic, namely, that letters are only external signs, a visible veiling of the actual truth, which is spiritual and invisible. ${ }^{41}$ This position of scepticism towards script is different from the view of Aristotle and rather reflects the view of Plato, who in his dialogue Phaidros narrates the anecdote of Thoth, the inventor of letters in Egypt. ${ }^{42}$ When he advertised it to King Thamos, Thoth claimed that this invention would make the Egyptians wiser and strengthen their memories. King Thamos replied that the opposite would be true; trusting in writing produced by external characters which are no part of ourselves would produce forgetfulness. In the remarks that follow his account of this myth, Plato puts writing and painting on the same level; both are dumb and lifeless. If one asks them, they cannot answer, and they always say the same words. Script is only a pale shadow or imitation of lively and inspired speech.

40 Assmann 1994, 327-329; Walter 1995.

41 Walter 1995, 377; Kiening 2008, 24.

42 Plato, Phaidros, 274d-276a. Assmann 1994. 
It is not surprising that in the third century Origen interprets Paul's formula and the contrast between letter and spirit in this sense. As he argues in De principiis:

'Littera occidit, spiritus autem vivificat'. In quo [apostolus] sine dubio per litteram corporalia significat, per spiritum intellectualia, quae et spiritualia dicimus.

'The letter kills, but the Spirit gives life'. By 'letter' [the apostle] undoubtedly means the physical things; by 'spirit' the intelligible ones, which we also call spiritual. ${ }^{43}$

Without a spiritual understanding of Scripture, and here Origen again quotes the apostle Paul (2 Cor. 3,15), velamen est positum super cor eorum ('a veil covers their hearts'), the truth remains veiled. In this sense, Paul's juxtaposition of littera and spiritus characterizes words and letters as visible but merely external and dead signs, written in ink or carved in stone, while the living truth is inscribed on the heart as immaterial, spiritual writing.

In this respect, the idea of the littera that kills and the life-giving spiritus can be related on the one hand to the doctrine of the multiple senses of Sacred Scripture, including allegory, as a method for interpreting texts, and, on the other hand, to the epistemological model that understands the knowledge and vision of God as a multi-level ascent from the material to the immaterial. Medieval exegetes agreed that the true, spiritual meaning of Sacred Scripture is hidden behind the literal meaning of words and letters. ${ }^{44}$ Like Paul and Origen, medieval theologians talked about this idea via metaphors of veiling and revealing. ${ }^{45}$

In the early ninth century, Claudius of Turin took Origen's argument literally, in part, and concisely explained the idea of the letter as a velamen ('veil'). ${ }^{46}$

Ita et cum per prophetas vel legislatorem Verbum Dei profertur ad homines, non absque competentibus profertur indumentis. Nam sicut ibi carnis, ita hic litterae velamine tegitur: ut littera quidem aspicitur tanquam caro, latens vero spiritalis intrinsecus sensus tanquam divinitas sentitur. [...] Beati sunt illi oculi qui velamen litterae obtectum intrinsecus divinum spiritum vident.

43 Origen, De principiis, I,1.2.

44 For the basics of this idea and its consequences for the medieval hermeneutics of Scripture, see the concise summary by Ohly 1958.

45 Spitz 1972, 23-39.

46 Claudius of Turin, In libros informationum litterae et spiritus, in Jacques-Paul Migne, Patrologia Latina, 104, 617AB. Translation by Smalley 1983, 1; Kessler 2000, 187. 
When the Word of God was shown to men through the lawgiver and the prophets, it was not shown them without suitable clothing. There it was covered by the veil of flesh, here by the veil of the letter. The letter appears as flesh; but the true spiritual sense within is known as divinity. [...] Blessed are the eyes which see divine spirit through the letters veil.

The true meaning of Sacred Scripture, the spiritual meaning, cannot be understood by simply reading the words; it is instead revealed through intensive consideration, continuous repetition of words and sentences, meditation, and careful thinking about the text. In medieval monasteries this way of reading was called ruminatio, which refers to the permanent and constantly repeated internalization of a text, as if one were ingesting and ruminating on it. ${ }^{47}$ This approach is fundamentally different from normal reading, that is, simple and cursory reading. For this reason, in examining the calligraphy of the initial pages, we may conclude that their writing does not have to obey the rules of normal reading. Instead, such pages activate a concentrated and meditative seeing of the text as the right way to understand the divine word and unveil its meaning.

This intent was often enhanced by the coloured or patterned pages which are often, as in the Morgan gospels, part of the introductory sequence. These pages evoke patterned textiles and are therefore to be understood as a visualization of the metaphor of velatio and revelatio, of veiling and unveiling. ${ }^{48}$ Such textile allusions can also be seen in the name of the gospel book, which changed in the eleventh century when it was increasingly no longer referred to as liber or codex but as textus Evangelii..$^{49}$ In this way, the twofold meaning of textus, as textile and as text, comes into play, both senses deriving from the Latin texere, which means 'to weave'. Not only textile background patterns but also the interweaving of letters and ornamentation, the under- and overlayering of letters, tendrils, and interlaced ornaments allude to this etymology and to the idea of the 'veil of the letter' concealing the truth.

The pages of the introductory series thus show, in summary, various forms of distance from the common, readable script. Especially the initial pages assume pictorial qualities and provoke a form of perception different from simple reading - more viewing and contemplation than just reading. ${ }^{50}$ In this way, the introductory pages can also be related to a widespread epistemological model originating in Antiquity, a model which understands the knowledge and vision of God as a gradual ascent from the material to the immaterial. This model

47 Ruppert 1977; Carruthers 1990, 164-166, 170-172; Illich 1993, 54-57.

48 Bücheler 2014, 70-114.

49 Lentes 2006.

50 Czerwinski 1997; Kiening 2008, 39-40. 
touches on the hermeneutics of Scripture as outlined above: the view behind the curtain of the script and the letters is not a physical viewing but rather a spiritual viewing and ultimately the vision of God.

In the twelfth century, especially in the school of Saint-Victor, the method of a knowledge that ascended in stages was widely discussed and systematized with a clear definition of terms. Its main features, however, can also be traced back to Antiquity and the Early Middle Ages. In his three-stage model, Hugh of Saint-Victor (c. 1096/7-1141) defines meditatio as the persistent pursuit of an object, which leads to contemplatio, the highest level of knowledge, which in turn grants access to the purely intelligible and therefore to the vision of God. ${ }^{51}$ Intensive reading in permanent repetition can thus be the starting point of meditation; interestingly, Augustine already saw a close connection between ruminatio and meditatio. ${ }^{52}$

The page sequence, which in early medieval gospel books is always placed at the beginning of a gospel, i.e. in an important, distinctive, and prominent position, can be understood as a visual reflection on writing, script, and the nature of Holy Scripture. The entire sequence offers readers a wide range of visual organization, writing surfaces with frames and coloured or patterned backgrounds and scripts that differ greatly from the continuously flowing text on the following pages. The sequence contains a wide spectrum that can include writing that is clearly legible, difficult to read and illegible, and even invisible, often staging an antithesis of enigmatic calligraphy and clear legibility. In this way, the sequence of pages activates different forms of perception that challenge normal reading. Within that sequence, it is above all in the initial pages that the rules of readable script, which is linearly ordered word by word, are demonstratively broken. Here the identification of the words is made impossible by abrupt changes in the size of the letters or the reading direction, by arbitrary grouping of the letters, and by ornamental interweaving: the initial pages are not organized as text pages, but as images and ornaments. ${ }^{53}$

The eye must walk on the page with careful and thorough consideration. The illegibility of the initial pages activates an attitude which makes the readers aware that there is a meaning behind the material and readable letters that must be revealed. Such pages therefore do not require reading in the usual sense, which linearly follows the succession of words. Their disposition as, often centralized (Figs 3 and 4), 'script-images' must be contemplated by simultaneous

51 Meier 1990, passim, esp. 40.

52 Ruppert 1977, 86-87.

53 Werckmeister 1967, 162-167. 
consideration and contemplative synopsis. Such consideration detaches itself from the material letter and enables the transition to contemplatio, to the highest level of knowledge. ${ }^{54}$

Understood in this way, these pages are proof of a great artistic dilemma. How could medieval artists, scribes, and painters, follow the apostle's doctrine that the letter kills, and only the invisible Spirit gives life? How could they show that their own work, the material script, is worthless? Their way out of this dilemma was a paradox that satisfied both artistic ambition and the demands of theology. It was precisely the most elaborate parts of the manuscript with ornamented letters and lavishly decorated script that drew attention to the worthlessness of material writing by their demonstratively presented illegibility. At the same time, the illegibility of the page was a visual cue for the transition from meditative reading to contemplatively seeing the purely intelligible, that is, to the visio Dei.

\section{References}

Alexander, Jonathan J. G. (1978), Initialen aus großen Handschriften, Munich: Prestel. Assmann, Aleida (1994), 'Schriftkritik und Schriftfaszination. Über einige Paradoxien im abendländischen Medienbewußtsein', in Susi Kotzinger and Gabriele Rippl (eds), Zeichen zwischen Klartext und Arabeske (Internationale Forschungen zur Allgemeinen und Vergleichenden Literaturwissenschaft, 7), Amsterdam: Rodopi, 327-336.

Assmann, Jan (1992), s.v. 'Schrift', in Joachim Ritter and Karlfried Gründer (eds), Historisches Wörterbuch der Philosophie, 8 (R-Sc), Basel: Schwabe, 1417-1429.

Bauer, Gerd (1977), Corvey oder Hildesheim. Zur ottonischen Buchmalerei in Norddeutschland, 2 vols, PhD dissertation, University of Hamburg.

Bonne, Jean-Claude (1996), 'Formes et fonctions de l'ornemental dans l'art médiéval (VIle-XIle siècle). Le modèle insulaire', in Jérôme Baschet and Jean-Claude Schmitt (eds), L'image. Fonctions et usages des images dans l'Occident médiéval (Cahiers du Léopard d'Or, 5), Paris: Léopard d'Or, 207-249.

Brown, Michelle P. (2017), 'The Visual Rhetoric of Insular Decorated Incipit Openings', in Brown et al. (eds) 2017, 127-142.

Brown, Michelle P., Ildar H. Garipzanov and Benjamin C. Tilghman (eds) (2017), Graphic Devices and the Early Decorated Book (Boydell studies in medieval art and architecture), Woodbridge: The Boydell Press.

Bücheler, Anna (2014), Ornament as Argument: Textile Pages and Textile Metaphors in Medieval German Manuscripts (800-1100), PhD thesis, University of Toronto.

54 Czerwinski 1997. In twelfth-century theories, contemplatio is supplemented by contuitus as a term for comprehensive synoptic vision; see Meier 1990, 41. 
Bücheler, Anna (2016), 'Textiles, Textile Pages, and Textile Iconography', in Juliane von Fircks and Regula Schorta (eds), Oriental Silks in Medieval Europe (Riggisberger Berichte, 21), Riggisberg: Abegg-Stiftung, 65-79.

Carruthers, Mary J. (1990), The Book of Memory: A Study of Memory in Medieval Culture (Cambridge Studies in Medieval Literature, 10), Cambridge: Cambridge University Press.

Christin, Anne-Marie (2016), 'Visible/Legible: An Iconic Typology of Writing', in Brigitte BedosRezak and Jeffrey Hamburger (eds), Sign and Design: Script as Image in Cross-cultural Perspective (300-1600 CE), Washington, D.C.: Dumbarton Oaks Research Library.

Czerwinski, Peter (1997), 'Verdichtete Schrift / comprehensiva scriptura. Prolegomena zu einer Theorie der Initiale', Internationales Archiv für Sozialgeschichte der deutschen Literatur, 22/2: 1-35.

Elbern, Victor H. (1983), 'Bildstruktur, Sinnzeichen, Bildaussage. Zusammenfassende Studie zur unfigürlichen Ikonographie im frühen Mittelalter’, Arte medievale, 1: 17-37.

Ernst, Ulrich (2006a), Facetten mittelalterlicher Schriftkultur. Fiktion und Illustration, Wissen und Wahrnehmung (Beihefte zum Euphorion, 51), Heidelberg: Winter.

Euw, Anton von (ed) (1991), Vor dem Jahr 1000. Abendländische Buchkunst zur Zeit der Kaiserin Theophanu [exhibition catalogue], Köln: Schnütgen-Museum.

Frese, Tobias (2014), '„Denn der Buchstabe tötet“ - Reflexionen zur Schriftpräsenz aus mediävistischer Perspektive', in Tobias Frese, Wilfried E. Keil and Kristina Krüger (eds), Verborgen, unsichtbar, unlesbar - zur Problematik restringierter Schriftpräsenz (Materiale Textkulturen, 2), Berlin: De Gruyter, 1-15.

Ganz, David (2016), 'Gelenkstellen von Bild und Schrift. Diptychen, Doppelseiten und Bucheinbände’, in David Ganz, and Marius Rimmele (eds), Klappeffekte. Faltbare Bildträger in der Vormoderne (Bild+Bild, 4), Berlin: Reimer, 55-108.

Ganz, David (2017a), 'Early Medieval Display Scripts and the Problems of How We See Them', in Ildar Garipzanov, Caroline Goodson and Henry Maguire (eds), Graphic Signs of Identity, Faith, and Power in Late Antiquity and the Early Middle Ages (Cursor mundi, 27), Turnhout: Brepols, 125-143.

Garipzanov, Ildar (2015), 'The Rise of Graphicacy in Late Antiquity and the Early Middle Ages', Viator 46/2: 1-21.

Garipzanov, Ildar H. (2017), “'In the Image and Likeness of God”: The Dedication Monogram in the Calendar of 354 and Early Medieval Monogrammatic Initials', in Brown et al. (eds) 2017, 15-30.

Gutbrod, Jürgen (1965), Die Initiale in Handschriften des achten bis dreizehnten Jahrhunderts, Stuttgart: Kohlhammer.

Hamburger, Jeffrey (2010), Ouvertures: La double page dans les manuscrits enluminés $d u$ Moyen Age, Lyon: Les Presses du réel.

Hamburger, Jeffrey F. (2011), 'The iconicity of script', Word \& Image, 27/3: 249-261.

Heinzer, Felix (2009), 'Die Inszenierung des Evangelienbuches in der Liturgie', in Stephan Müller, Lieselotte E. Saurma-Jeltsch and Peter Strohschneider (eds), Codex und Raum (Wolfenbütteler Mittelalter-Studien, 21), Wiesbaden: Harrassowitz, 43-58.

Illich, Ivan (1993), In the Vineyard of the Text: A Commentary to Hugh's Didascalicon, Chicago: University of Chicago Press, 1996 [translation of L'Ėre du livre, Paris: Les Éditions du Cerf 1990; German translation Im Weinberg des Textes. Frankfurt am Main: Luchterhand 1991].

Irvine, Martin (1994), The Making of Textual Culture: 'Grammatica' and Literary Theory 3501100 (Cambridge Studies in Medieval Literature, 19), Cambridge: Cambridge University Press. 
Jakobi-Mirwald, Christine (2004), Das mittelalterliche Buch. Funktion und Ausstattung, Stuttgart: Reclam.

Kahsnitz, Rainer (2001), 'Evangeliar in Leipzig', in Matthias Puhle (ed) Otto der Große. Magdeburg und Europa [exhibition catalogue: 27. Ausstellung des Europarates und Landesausstellung Sachsen-Anhalt], vol. 2, Mainz: von Zabern, 177-179, no. IV.8.

Karkov, Catherine E. (2017), 'Tangled Voices: Writing, Drawing and the Anglo-Saxon Decorated Initial', in Brown et al. (eds) 2017, 45-62.

Kendrick, Laura (1999), Animating the Letter: The Figurative Embodiment of Writing from Late Antiquity to the Renaissance, Columbus: The Ohio State University Press.

Kiening, Christian (2008), 'Die erhabene Schrift. Vom Mittelalter zur Moderne', in Kiening and Stercken (2008), 9-126.

Kiening, Christian and Marina Stercken (2008), SchriftRäume. Dimensionen von Schrift zwischen Mittelalter und Moderne (Medienwandel, Medienwechsel, Medienwissen, 4), Zürich: Chronos.

Krämer, Sybille, Eva Cancik-Kirschbaum and Rainer Totzke (eds) (2012), Schriftbildlichkeit: Wahrnehmbarkeit, Materialität und Operativität von Notationen, Berlin: Akademie.

Lentes, Thomas (2006), 'Textus Evangelii. Materialität und Inszenierung des textus in der Liturgie', in Ludolf Kuchenbuch and Uta Kleine (eds), 'Textus' im Mittelalter (Veröffentlichungen des Max-Planck-Instituts für Geschichte, 26), Göttingen: Vandenhoeck \& Ruprecht, 133-148.

Lewis, Suzanne (1980), 'Sacred Calligraphy: The Chi Rho Page in the Book of Kells', Traditio, 36: 139-159.

Loic, Erika (2020), 'The Letter as Presence, Process, and Partnership: Mergers of Message and Medium in the Medieval Initial', Visual Resources, 36/2: 148-74.

Märker, Peter and Theo Jülich (eds) (2001), Gold und Purpur. Der Bilderschmuck der früh- und hochmittelalterlichen Handschriften aus der Sammlung Hüpsch im Hessischen Landesmuseum Darmstadt, exhibition catalogue, Darmstadt: Hessisches Landesmuseum.

Meier, Christel (1990), 'Malerei des Unsichtbaren. Über den Zusammenhang von Erkenntnistheorie und Bildstruktur im Mittelalter', in Wolfgang Harms (ed.), Text und Bild. Bild und Text (Germanistische Symposien-Berichtsbände, 11), Stuttgart: J.B. Metzler, 35-65.

Nordenfalk, Carl (1970), Die spätantiken Zierbuchstaben (Die Bücherornamentik der Spätantike, 2), vol. 1 [Text], Stockholm: Nordenfalk.

O’Driscoll, Joshua (2011), 'Visual vortex: an epigraphic image from an Ottonian gospel book', Word \& Image, 27/3: 309-321.

Ohly, Friedrich (1958), 'Vom geistigen Sinn des Wortes im Mittelalter', Zeitschrift für deutsches Altertum und deutsche Literatur, 89:1-23 [repr. in Friedrich Ohly, Schriften zur mittelalterlichen Bedeutungsforschung, Darmstadt: Wissenschaftliche Buchgesellschaft, 1977, 1-31].

Pächt, Otto (1985), Buchmalerei des Mittelalters. Eine Einführung, 2nd edn, Munich: Prestel.

Palazzo, Eric (2010), 'Le “livre-corps" à l'époque carolingienne et son rôle dans la liturgie de la messe et sa théologie', Quaestiones Medii Aevi Novae, 15: 31-63.

Polaschegg, Andrea (2018), 'Enigmatische Ästhetik. Zur Kulturgeschichte unlesbarer Schrift und ihrer künstlerischen Transformation', in Jutta Müller-Tamm, Caroline Schubert and Klaus Ulrich Werner (eds), Schreiben als Ereignis. Künste und Kulturen der Schrift (Zur Genealogie des Schreibens, 23), Paderborn: Wilhelm Fink, 173-197.

Reudenbach, Bruno (2014), 'Der Codex als Verkörperung Christi. Mediengeschichtliche, theologische und ikonographische Aspekte einer Leitidee früher Evangelienbücher', in 
Joachim Friedrich Quack and Daniela Christina Luft (eds), Erscheinungsformen und Handhabungen Heiliger Schriften (Materiale Textkulturen, 5), Berlin: De Gruyter, 231-246.

Rohrbach, Lena (2008), 'Aura', in Kiening and Stercken (eds) (2008), 199-206.

Ruppert, Fidelis (1977), 'Meditatio - Ruminatio. Zu einem Grundbegriff christlicher Meditation', Benediktinische Montasschrift. Erbe und Auftrag, 53: 83-93.

Schneider, Wolfgang Christian (2000), 'Geschlossene Bücher - offene Bücher. Das Öffnen von Sinnräumen im Schließen der Codices', Historische Zeitschrift, 271: 561-592.

Schneider, Wolfgang Christian (2002), 'Die “Aufführung” von Bildern beim Wenden der Blätter in mittelalterlichen Codices. Zur performativen Dimension von Werken der Buchmalerei', Zeitschrift für Ästhetik und Allgemeine Kunstwissenschaft, 47: 7-35.

Schreiner, Klaus (2002), 'Litterae mysticae. Symbolik und Pragmatik heiliger Buchstaben, Texte und Bücher in Kirche und Gesellschaft des Mittelalters', in Christel Meier, Volker Honemann, Hagen Keller and Rudolf Suntrup (eds), Pragmatische Dimensionen mittelalterlicher Schriftkultur (Münstersche Mittelalter-Schriften, 79), Munich: Fink, 277-337.

Smalley, Beryl (1983), The Study of the Bible in the Middle Ages, 3rd rev. edn, Oxford: Blackwell [1st edn: 1941].

Spitz, Hans-Jörg (1972), Die Metaphorik des geistigen Schriftsinns. Ein Beitrag zur allegorischen Bibelauslegung des ersten christlichen Jahrtausends (Münstersche MittelalterSchriften, 12), Munich: Fink.

Tilghman, Benjamin C. (2011a), 'The shape of the word: extralinguistic meaning in insular display lettering', Word \& Image, 27/3: 292-308.

Tilghman, Benjamin C. (2011b), 'Writing in Tongues: Mixed Scripts and Style in Insular Art', in Colum Hourihane (ed), Insular and Anglo-Saxon Art and Thought in the Early Medieval Period (The Index of Christian Art: Occasional Papers, 13), Princeton, NJ: Pennsylvania State University Press, 93-108.

Tilghman, Benjamin C. (2016), 'Ornament and Incarnation in Insular Art', Gesta, 55/2: 158-177. Tilghman, Benjamin C. (2017), 'Patterns of Meaning in Insular Manuscripts: Folio 183r in the Book of Kells', in Brown et al. (eds) 2017, 163-178.

Toubert, Hélène (1990), 'La double page illustrée', in Henri-Jean Martin and Jean Vezin (eds), Mise en page et mise en texte du livre manuscrit, Paris: Éditions du Cercle de la Librairie / Promodis, 373-378.

Vogt-Spira, Gregor (1991), 'Vox und Littera. Der Buchstabe zwischen Mündlichkeit und Schriftlichkeit in der grammatischen Tradition', Poetica. Zeitschrift für Sprach- und Literaturwissenschaft, 23: 295-327.

Walter, Peter (1995), s.v. 'Geist u. Buchstabe', in Lexikon für Theologie und Kirche, vol. 4, 3rd edn, Freiburg i. Br.: Herder.

Werckmeister, Otto Karl (1964), 'Die Bedeutung der “Chi” Initialseite im Book of Kells', in Kurt Böhner and Victor H. Elbern (eds), Das erste Jahrtausend. Kultur und Kunst im werdenden Abendland an Rhein und Ruhr, text vol. 2, Düsseldorf: Schwann, 687-710.

Werckmeister, Otto Karl (1967), Irisch-northumbrische Buchmalerei des 8. Jahrhunderts und monastische Spiritualität, Berlin: De Gruyter.

Wieck, Roger S. (1996), 'Folia Fugitiva: The Pursuit of the Illuminated Manuscript Leaf', The Journal of the Walters Art Gallery, 54: 233-254. 


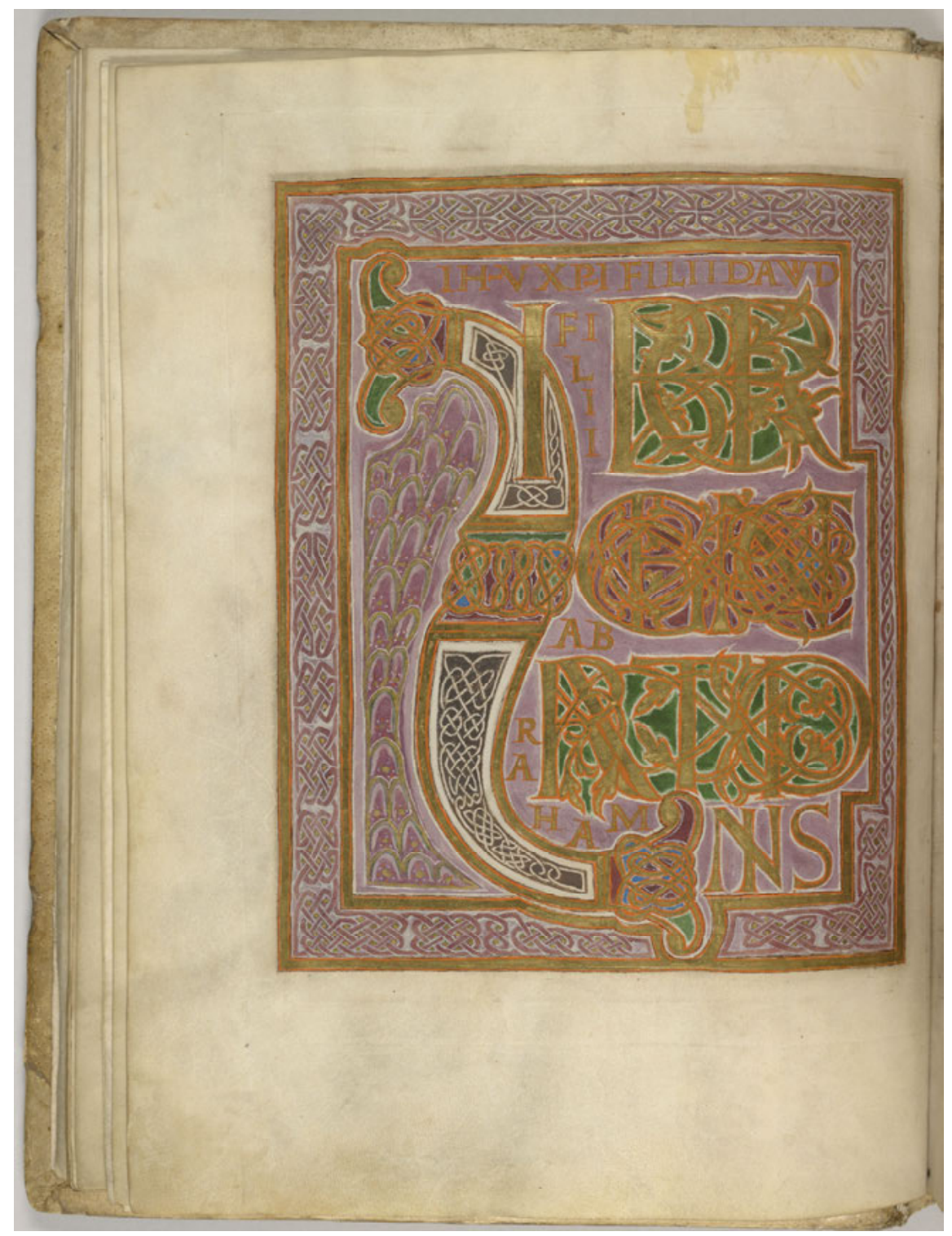

Fig. 1: Gospel book from Corvey, $9^{\text {th }}$ C.; New York, Pierpont Morgan Library, M. 755, fol. $17^{\mathrm{v}}$ : LIBER GENERATIONIS IHV XRI FILII DAVID FILII ABRAHAM. @ The Morgan Library \& Museum, New York. 


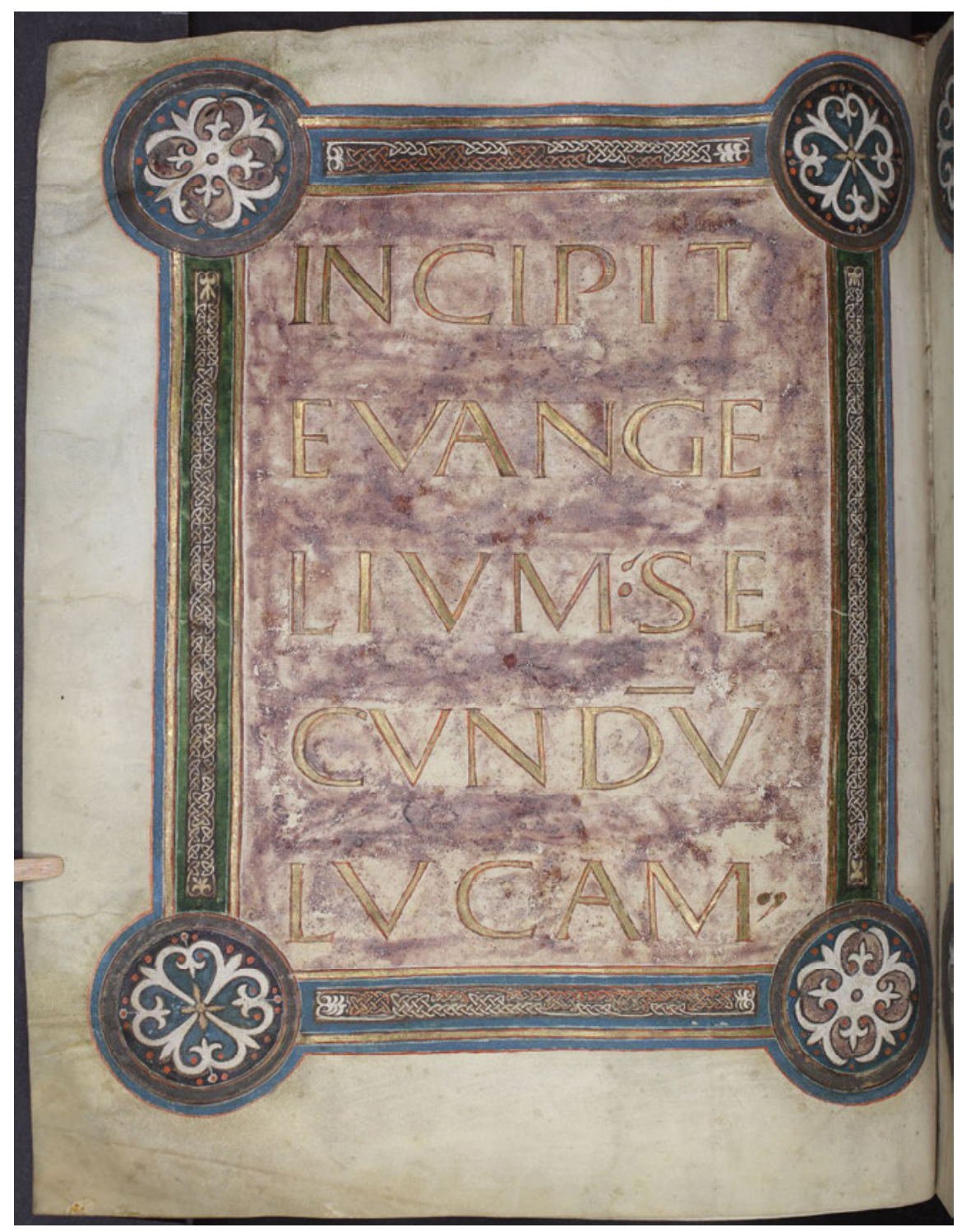

Fig. 2: Gospel book from Corvey, $9^{\text {th }}$ c.; Leipzig, Universitätsbibliothek, Ms 76, fol. $109^{\mathrm{v}}$ : INCIPIT EVANGELIVM SECVNDVM LVCAM. (C) Universitätsbibliothek, Leipzig. 


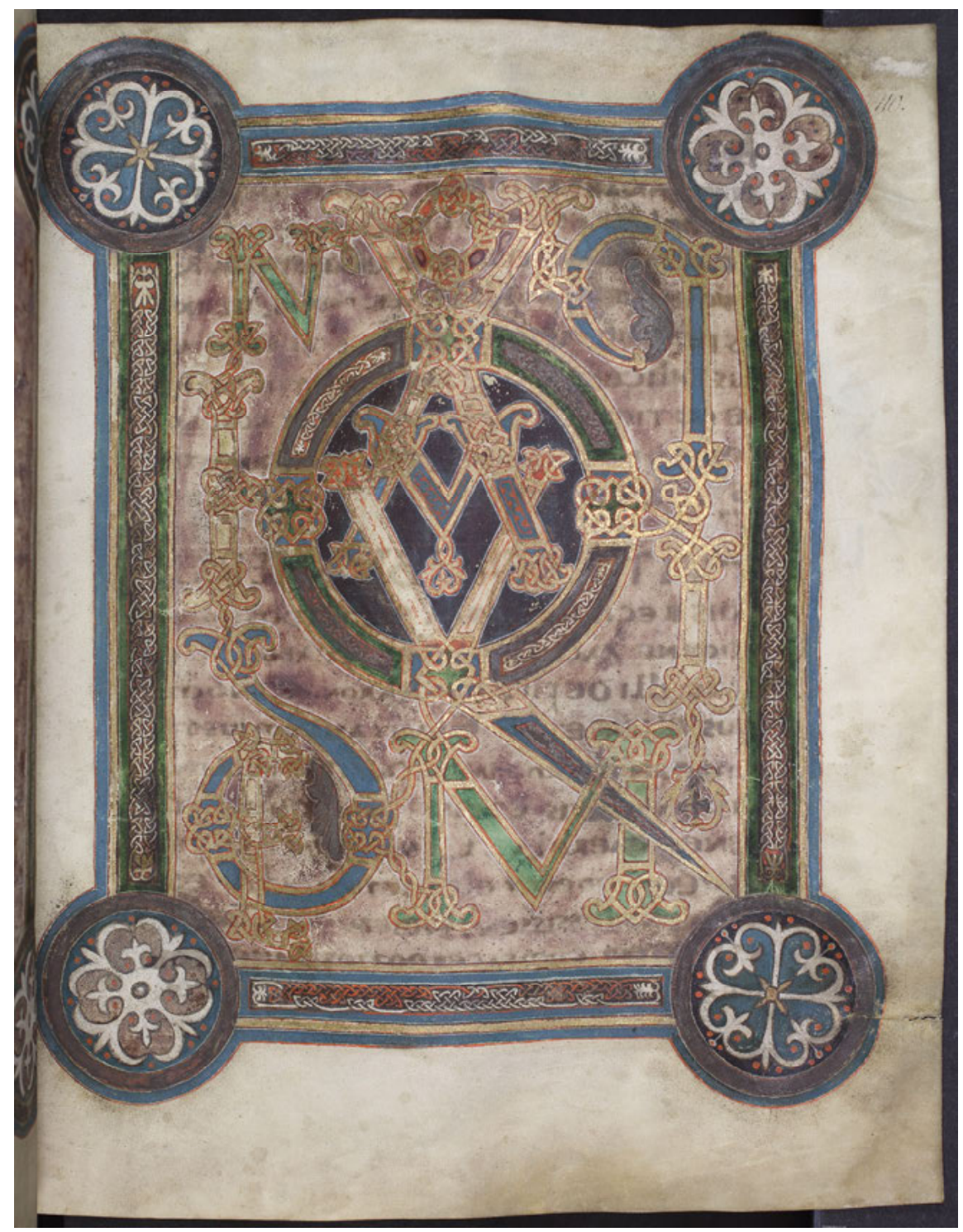

Fig. 3: Gospel book from Corvey, $9^{\text {th }}$ c.; Leipzig, Universitätsbibliothek, Ms 76, fol. $110^{\text {r }}$ : QVONIAM QVIDEM. @ Universitätsbibliothek, Leipzig. 


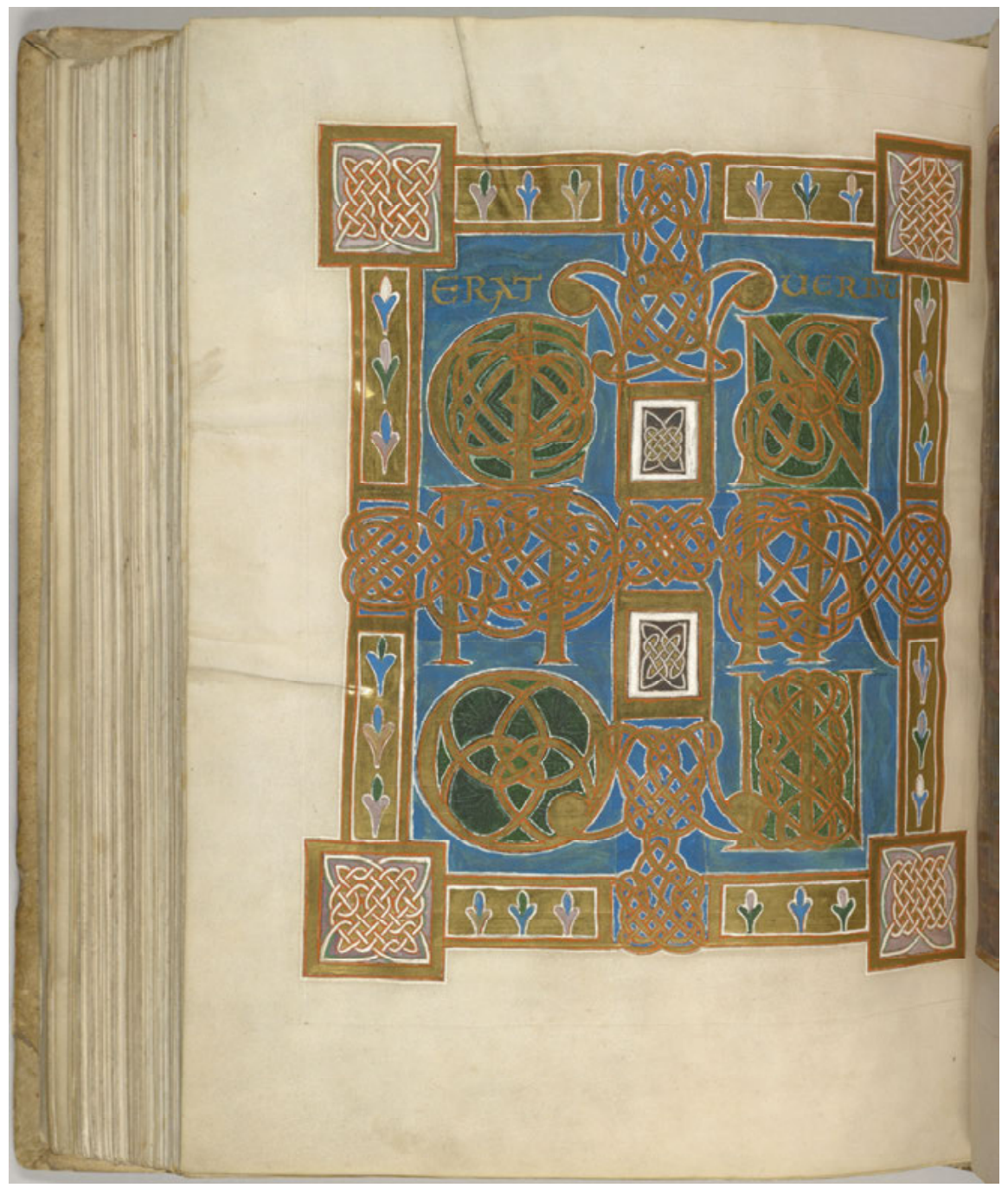

Fig. 4: Gospel book from Corvey, $9^{\text {th }}$ C.; New York, Pierpont Morgan Library, M. 755, fol. 157 : IN PRINCIPIO ERAT VERBVM. ( ) The Morgan Library \& Museum, New York. 